"This document is the Accepted Manuscript version of a Published Work that appeared in final form in Inorganic Chemistry, copyright (C2017 American Chemical Society after peer review and technical editing by the publisher. To access the final edited and published work see:

http://pubs.acs.org/doi/abs/10.1021/acs.inorgchem.7b02375

\title{
Synthesis, Structure and Redox Properties of a trans-Diaqua Ru Complex that Reaches Seven Coordination at High Oxidation States
}

Roc Matheu, ${ }^{\mathrm{a}, \mathrm{b}}$ Jordi Benet-Buchholz, ${ }^{\mathrm{a}}$ Xavier Sala*,c and Antoni Llobet*,a,c

a Institute of Chemical Research of Catalonia (ICIQ), Avinguda Països Catalans 16, 43007

Tarragona, Spain.

${ }^{\text {b }}$ Departament de Química Física i Inorgànica, Universitat Rovira i Virgili, Marcel·lí Domingo s/n, 43007 Tarragona, Spain.

c Departament de Química, Universitat Autònoma de Barcelona, Cerdanyola del Vallès, 08193 Barcelona, Spain.

Corresponding authors: xavier.sala@uab.cat; allobet@iciq.cat 


\begin{abstract}
In this work we have prepared and characterized two Ru complexes that contain the pentadenatate $\mathrm{tda}^{2-}$ ligand ( $\mathrm{tda}^{2-}=\left[2,2^{\prime}: 6^{\prime}, 2^{\prime \prime}\right.$-terpyridine $]-6,6^{\prime \prime}$-dicarboxylate) that occupies the equatorial positions and two monodentate ligands aqua and/or dmso occupy the axial positons: [trans-Ru' ${ }^{\prime \prime \prime}\left(\right.$ tda- $\left.\left.\kappa-\mathrm{N}^{3} \mathrm{O}\right)\left(\mathrm{OH}_{2}{ }^{\mathrm{ax}}\right)_{2}\right]^{+}, 3^{\prime \prime \prime}\left(\mathrm{OH}_{2}\right)_{2}{ }^{+}$and $\left[\mathrm{Ru}\right.$ "'(tda- $\left.\left.\kappa-\mathrm{N}^{3} \mathrm{O}\right)(\mathrm{dmso})\left(\mathrm{OH}_{2}{ }^{\mathrm{ax}}\right)\right], 4^{\prime \prime}$. The latter is a useful synthetic intermediate for the preparation of Ru-tda complexes with different axial ligands. The two complexes have been characterized in the solid state by single-crystal XRD and

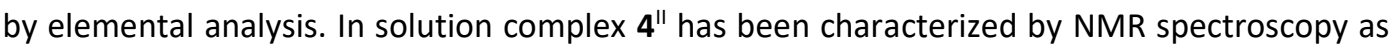
well as the one electron reduction of complex $3^{\prime \prime \prime}\left(\mathrm{OH}_{2}\right)_{2}{ }^{+}$. The electrochemical properties of $3^{\text {III }}\left(\mathrm{OH}_{2}\right)_{2}{ }^{+}$and $4^{\prime \prime}$ have been assessed by cyclic voltammetry (CV) and differential pulse voltammetry (DPV). Complex $3^{\prime \prime \prime}\left(\mathrm{OH}_{2}\right)_{2}{ }^{+}$shows the presence of four redox waves that are assigned to the $\mathrm{VI} / \mathrm{V}, \mathrm{V} / \mathrm{IV}, \mathrm{IV} / \mathrm{III}$ and III/II redox couples. The variation of the redox potentials is analyzed as a function of $\mathrm{pH}$ and is graphically presented as a Pourbaix diagram. Finally, the redox potentials displayed by both $3^{\prime \prime \prime}\left(\mathrm{OH}_{2}\right)_{2}{ }^{+}$and $4^{\prime \prime}$ are compared to related complexes previously reported in the literature and rationalized based on the electron donating or withdrawing capacity of the auxiliary ligands as well as with regard to their ability to undergo seven coordination at high oxidation states.
\end{abstract}

Keywords: Ru complexes, seven coordination, redox properties, trans-dioxo, trans-aqua, water oxidation. 


\section{Introduction}

Ruthenium complexes constitute one of the richest families of coordination compounds partly thanks to the large number of formal oxidation states that Ru can access, ranging from -3 up to $+8 .^{1}$ These complexes have a myriad of applications in many fields including, photochemistry and photophysics, ${ }^{2,3}$ bioinorganic chemistry ${ }^{4,5}$ and catalysis. ${ }^{6,7}$ From a catalytic perspective, Ru complexes are active in a large number of reactions involving $\mathrm{C}-\mathrm{C}$ coupling, ${ }^{6} \mathrm{C}-\mathrm{H}$ insertion and especially in redox catalysis with organic transformations. ${ }^{7}$ The latter includes the oxidation of alkenes to epoxides, sulfides to sulfoxides, alcohols to aldehydes and carboxylic acid. ${ }^{8}$ Particularly interesting is the application of Ru complexes for the catalytic oxidation of water to dioxygen, a reaction of interest within the context of new renewable energy conversion schemes. . $^{9,10,11,12}$

For redox catalysis, one of the unavoidable requirements to display significant redox activity is the presence of a Ru- $\mathrm{OH}_{2}$ group in the complex. . $^{13,14,15,16}$ This allows to reach reactive high oxidation states via proton-coupled electron transfer at a relatively low energy. ${ }^{17,18}$ For the particular case of the water oxidation, the best catalysts described so far involve the formation of seven coordinate complexes at high oxidations states, stabilized by sigma donor groups such as carboxylates. . $^{19,20,21,22,23,24}$

A good example of this family of catalysts is the $\left[\mathrm{Ru}^{\mathrm{IV}}\left(\mathrm{tda}-\kappa-\mathrm{N}^{3} \mathrm{O}\right)(\mathrm{py})_{2}\left(\mathrm{OH}^{\mathrm{eq}}\right)\right]^{+}$complex, $\mathbf{1}^{\mathrm{IV}}(\mathrm{OH})^{+}$, where $\mathrm{tda}^{2-}$ is the pentadentate ligand $\left(\left[2,2^{\prime}: 6^{\prime}, 2^{\prime \prime}\right.\right.$-terpyridine]-6,6"-dicarboxylate), py is pyridine and $\mathrm{OH}^{\mathrm{eq}}$ is a hydroxido ligand bonded to the metal center at the equatorial position, see Chart 1 and 2. Complex $\mathbf{1}^{1 \mathrm{~V}}(\mathbf{O H})^{+}$is today the fastest water oxidation catalysts reported achieving maximum turnover frequencies $\left(T O F_{\max }\right)$ of $50,000 \mathrm{~s}^{-1}$ at $p H=10.0 .{ }^{20} \mathrm{In}$ sharp contrast, the $\left[\mathrm{Ru}^{\mathrm{IV}}\left(\mathrm{tda}-\mathrm{K}-\mathrm{N}^{3} \mathrm{O}\right)(\mathrm{py})\left(\mathrm{OH}^{\mathrm{ax}}\right)\right]$ complex, $\mathbf{2}^{\mathrm{lv}}(\mathrm{OH})^{+}$, where the hydroxido group is placed the axial position, is a poor catalyst. ${ }^{25}$

Here on we report the synthesis and spectral and redox properties of a new member of the Rutda family of complexes, trans-[Ru'l'(tda- $\left.\left.-\mathrm{N}^{3} \mathrm{O}\right)\left(\mathrm{H}_{2} \mathrm{O}^{\mathrm{ax}}\right)_{2}\right], 3^{\prime \prime \prime}\left(\mathrm{H}_{2} \mathrm{O}\right)_{2}{ }^{+}$. The properties of the complex are compared with the rest of the members of the family and with other relevant complexes previously described in the literature. In addition, we report a new complex [Ru"(tda$\left.\left.\kappa-\mathrm{N}^{3} \mathrm{O}\right)(\mathrm{dmso})\left(\mathrm{H}_{2} \mathrm{O}\right)\right], 4^{\prime \prime}$, that is an excellent synthetic intermediate for the preparation of all the family of Ru-tda complexes.

\section{Experimental Section}

\section{Materials}

\section{$\underline{\text { General Materials }}$}

Solvents and products were provided by Sigma-Aldrich unless indicated. [2,2':6',2"-terpyridine]6,6"-dicarboxylic acid $\left(\mathrm{H}_{2} \mathrm{tda}\right)^{26}$ and $\left[\mathrm{Ru}^{\prime \prime} \mathrm{Cl}_{2}(\mathrm{dmso})_{4}\right]^{27}$ were synthesized and purified according to the literature. High-purity deionized water was obtained by passing distilled water through a nanopure Milli-Q water purification system. 
Synthesis of [Ru(tda- $\left.\left.\kappa-\mathrm{N}^{3} \mathrm{O}\right)(\mathrm{dmso})\left(\mathrm{OH}_{2}{ }^{\mathrm{ax}}\right)\right], 4^{\prime \prime}$. [Ru' $\left.\mathrm{Rl}_{2}(\mathrm{dmso})_{4}\right](150 \mathrm{mg}, 0.31 \mathrm{mmol}), 2^{\prime}, 2^{\prime \prime}: 6^{\prime}, 2^{\prime \prime}-$ terpyridine-6', 6"-dicarboxylic acid ( $\left.\mathrm{H}_{2} \mathrm{tda}\right)(99 \mathrm{mg}, 0.31 \mathrm{mmol})$ and $\mathrm{Et}_{3} \mathrm{~N}(0.3 \mathrm{~mL})$ were degassed in dry methanol $(6 \mathrm{~mL})$, refluxed for 6 hours and cooled down to RT. A brown solid (100 $\mathrm{mg}$ ) appeared in the reaction mixture and was filtered, washed with methanol and diethyl ether. The solid was dissolved in water $(30 \mathrm{~mL})$ and the mixture was heated at $60^{\circ} \mathrm{C}$ until all the solid was completely dissolved. Then, the solvent was evaporated and the resulting solid was washed with acetone and diethyl ether and dried under vacuum (90 mg, $50 \%$ yield). Crystals suitable for single-crystal X-Ray Diffraction (XRD) were collected after water solvent of a $\mathbf{4}^{\text {" }}$ solution at $\mathrm{pH}=$ 1.0 ( $1 \mathrm{mM}$ ) slowly evaporated. ${ }^{1} \mathrm{H}$ NMR $\left(500 \mathrm{MHz}, \mathrm{D}_{2} \mathrm{O}\right) \delta: 2.63(6 \mathrm{H}, \mathrm{s}), 8.13(1 \mathrm{H}, \mathrm{t}, J=8.1 \mathrm{~Hz})$, $8.27(2 \mathrm{H}, \mathrm{t}, J=7.8 \mathrm{~Hz}), 8.32(2 \mathrm{H}, \mathrm{dd}, J=7.8,1.3 \mathrm{~Hz}), 8.40(2 \mathrm{H}, \mathrm{d}, J=8.1 \mathrm{~Hz}), 8.47(2 \mathrm{H}, \mathrm{dd}, J=$ 7.8, $1.3 \mathrm{~Hz}$ ).). ${ }^{13} \mathrm{C}$ NMR $\left(500 \mathrm{~Hz}, \mathrm{D}_{2} \mathrm{O}\right)$ 8: 42.7, 115.8, 118.3, 120.8, 123.4, 123.6, 124.4, 126.2, 128.2, 137.6, 140.1, 152.7, 158.8, 160.3, 170.0. HRMS m/z: Calc. for $\left[4-\mathrm{H}_{2} \mathrm{O}+\mathrm{Na}\right]^{+}$ $\left(\mathrm{C}_{19} \mathrm{H}_{15} \mathrm{~N}_{3} \mathrm{NaO}_{5} \mathrm{RuS}^{+}\right):$521.9668. Found m/z: 521.9672. Anal. Calc. for [4+ $\left.\mathrm{H}_{2} \mathrm{O}\right]: \mathrm{C}, 42.7 ; \mathrm{H}, 3.6 ; \mathrm{N}$, 7.9; S: 5.9. Found: $\mathrm{C}, 42.4 ; \mathrm{H}, 3.2 ; \mathrm{N}, 7.7 ; \mathrm{S}, 5.9 \%$.

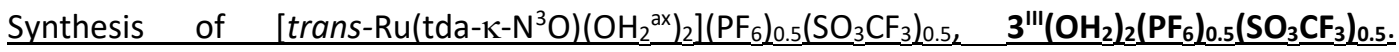
Complex 4" (100 mg, $0.19 \mathrm{mmol}$ ) was dissolved in $0.3 \mathrm{~mL}$ of neat triflic acid and heated to 100 ${ }^{\circ} \mathrm{C}$ for 4 hours and cooled to room temperature. Then, an aqueous saturated $\mathrm{KPF}_{6}$ solution (3.6 $\mathrm{mL}$ ) was added and the mixture was kept in the fridge for 2 hours. During this period, crystals suitable for XRD appeared as a precipitate (90 mg, $75 \%) .{ }^{1} \mathrm{H}-\mathrm{NMR}\left(500 \mathrm{~Hz}, \mathrm{D}_{2} \mathrm{O}+\right.$ ascorbic acid)

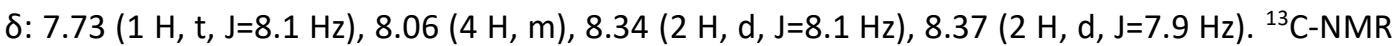
(500 Hz, $\mathrm{D}_{2} \mathrm{O}+$ ascorbic acid) 122.3, 123.1, 125.3, 132.0, 137.1, 158.6, 160.2, 164.1, 173.3. HRMS m/z: Calc. for [3 $\left.3^{\prime \prime \prime}\left(\mathrm{OH}_{2}\right)_{2}{ }^{+}-\mathrm{H}_{2} \mathrm{O}\right]\left(\mathrm{C}_{17} \mathrm{H}_{9} \mathrm{~N}_{3} \mathrm{O}_{4} \mathrm{Ru}\right): 420.9637$, found m/z: 420.9649 (2.9 ppm). Anal. Calc. for: $\left[3^{\prime \prime \prime}\left(\mathrm{OH}_{2}\right)_{2}{ }^{+}+0.1 \cdot \mathrm{CF}_{3} \mathrm{SO}_{3} \mathrm{H}+\mathrm{H}_{2} \mathrm{O}\right]\left\{\mathrm{PF}_{6}\right\}_{0.5}\left\{\mathrm{SO}_{3} \mathrm{CF}_{3}\right\}_{0.5}\left(\mathrm{C}_{17.6} \mathrm{H}_{15.1} \mathrm{~F}_{4.8} \mathrm{~N}_{3} \mathrm{O}_{8.8} \mathrm{P}_{0.5} \mathrm{RuS}_{0.6}\right): \mathrm{C}, 33.2$; $\mathrm{H}, 2.4 ; \mathrm{N}, 6.6$; S, 3.0. Found: $\mathrm{C}, 33.1 ; \mathrm{H}, 2.4 ; \mathrm{N}, 6.4 ; \mathrm{S}, 3.3 \%$.

Synthesis of $\left[\mathrm{Ru}\left(\mathrm{tda}-\kappa-\mathrm{N}^{3} \mathrm{O}\right)(\mathrm{py})\left(\mathrm{SO}\left(\mathrm{CH}_{3}\right)_{2}\right)\right]_{2} 5^{\prime \prime}$. The synthesis was adapted from the literature but using complex $4^{\prime \prime}$ as starting material. ${ }^{25}$ Complex $4^{\prime \prime}(50 \mathrm{mg}, 0.1 \mathrm{mmol})$ was dissolved in a mixture of water $(2.5 \mathrm{~mL})$ and pyridine $(7.5 \mathrm{~mL})$. The solution was stirred for 2 days at room temperature. The brown solution was washed with dichloromethane $(3 \times 100 \mathrm{~mL})$ and the organic phase was discarded. Then, the aqueous solution was reduced to dryness under low pressure. The brown solid obtained in this way was re-dissolved in methanol. Upon addition of diethyl ether, a brown solid appeared that was filtered and dried under vacuum ( $44 \mathrm{mg}, 0.14$ mmol, $75 \%$ yield). The purity of the product was confirmed by ${ }^{1} \mathrm{H}$ NMR and electrochemistry. ${ }^{25}$

Synthesis of $\left[R u\left(t d a-\kappa-N^{3} \mathrm{O}\right)(p y)_{2} l_{2} 6^{\prime \prime}\right.$. The synthesis was adapted from the literature using complex $4^{\prime \prime}$ as starting material. ${ }^{20}$ Complex $4^{11}(50 \mathrm{mg}, 0.1 \mathrm{mmol})$ was dissolved in a mixture of water $(2.5 \mathrm{~mL})$ and pyridine $(7.5 \mathrm{~mL})$. The solution was stirred overnight at reflux temperature. The resulting brown solution was washed with dichloromethane $(3 \times 100 \mathrm{~mL})$ and the organic phase was discarded. Then, the aqueous solution was reduced to dryness under low pressure. The brown solid obtained in this way was re-dissolved in methanol. Upon addition of diethyl ether a brown solid appeared that was filtered and dried under vacuum (40 mg, $70 \%$ yield). The purity of the product was confirmed by ${ }^{1} \mathrm{H}$ NMR and electrochemistry. ${ }^{20}$

Solutions at $\mathrm{pH}=1.0, \mathrm{pH}=7.0$ and $\mathrm{pH}=12.0 . \mathrm{pH}=1.0$ triflic acid $\left(\mathrm{CF}_{3} \mathrm{SO}_{3} \mathrm{H}\right)$ solution $(I=0.1 \mathrm{M})$ : A sample of neat triflic acid ( $10 \mathrm{~g}, 0.0663$ mols) was diluted with $662 \mathrm{~mL}$ of deionised water. $\mathrm{pH}$ $=7.0$ phosphate buffered solution $(I=0.1 \mathrm{M})$ : A sample of $\mathrm{NaH}_{2} \mathrm{PO} 4(2.31 \mathrm{~g}, 0.0193 \mathrm{M})$ and 
$\mathrm{Na}_{2} \mathrm{HPO}_{4}(3.77 \mathrm{~g}, 0.0266 \mathrm{M})$ were dissolved in deionised water up to $1 \mathrm{~L} . A \mathrm{pH}=12.0$ phosphate buffer solution $(I=0.1 \mathrm{M})$ : A sample of $\mathrm{Na}_{2} \mathrm{HPO}_{4}(10.293 \mathrm{~g}, 0.0073 \mathrm{M})$ and $\mathrm{Na}_{3} \mathrm{PO}_{4}(2.06 \mathrm{~g}, 0.0126$ $\mathrm{M})$ were dissolved with deionised water up to $1 \mathrm{~L}$.

\section{Instrumentation and Methods}

General Instrumentation and Methods. Electrospray ionization (ESI)) mass spectrometry (MS) experiments were performed on a Waters Micromass LCT Premier equipment. A Bruker Avance $500 \mathrm{MHz}$ were used to carry out NMR spectroscopy. The $\mathrm{pH}$ of the solutions was determined by a $\mathrm{pH}$-meter (CRISON, Basic $20^{+}$) calibrated before measurements through standard solutions at $p H=4.01,7.00$ and 9.21 .

Electrochemical methods. All electrochemical experiments were performed in an IJ-Cambria HI730 bipotentiostat, using a three-electrode cell. A $20 \mathrm{~mL}$ vial was used as an electrochemical cell. A Teflon-made with holes for the three electrodes was used as a lid to ensure a reproducible distance between the electrodes. Glassy carbon disk $\left(\phi=0.3 \mathrm{~cm}, \mathrm{~S}=0.07 \mathrm{~cm}^{2}\right)$ and Pt disk were used as Working Electrode (WE) and Counter Electrode (CE) respectively. Glassy carbon electrodes were polished with $0.05 \mu \mathrm{m}$ alumina $\left(\mathrm{Al}_{2} \mathrm{O}_{3}\right)$ and washed with water. The Reference Electrode ( $\mathrm{RE}$ ) was $\mathrm{Hg} / \mathrm{Hg}_{2} \mathrm{SO}_{4}\left(\mathrm{~K}_{2} \mathrm{SO}_{4}\right.$ saturated) and potentials were converted to $\mathrm{NHE}$ by adding 0.65 V. CVs and DPVs were iR compensated (90\%). Cyclic Voltammograms (CV) were recorded at $100 \mathrm{mV} \cdot \mathrm{s}^{-1}$ scan rate. The DPV parameters were $\Delta \mathrm{E}=4 \mathrm{mV}$, Pulse width $=5 \mathrm{~s}$, Sampling width $=0.0167 \mathrm{~s}$, Pulse period $=5 \mathrm{~s}$.

Pourbaix diagram. Three solutions of $3^{\prime \prime \prime}\left(\mathrm{OH}_{2}\right)_{2}{ }^{+}(\sim 0.5 \mathrm{mM})$ were prepared at $\mathrm{pH}=1.0, \mathrm{pH}=7.0$ and at $p H=12.0$. The three solutions contained an ionic strength of $0.1 \mathrm{M}$. The three solutions containing complex $3^{\prime \prime \prime}\left(\mathrm{OH}_{2}\right)_{2}{ }^{+}$were mixed in order to obtain the desired $\mathrm{pH}$, which was measured by the use of a $p H$ meter. CV and DPV experiments were performed to analyze the solution at each $\mathrm{pH}$. Due to the irreversibility of the VI/V and V/IV redox couple, DPV was used to extract the $E_{1 / 2}$ values for the Pourbaix diagram.

Single-Crystal XRD Methods. The measured crystals were prepared under inert conditions immersed in perfluoropolyether as protecting oil for manipulation. Crystal structure determinations for $\mathbf{8}\left(\mathbf{4}^{\prime \prime}+\mathbf{7}^{\prime \prime \prime}\right)^{+}$and $\mathbf{3}^{\prime \prime \prime}\left(\mathbf{O H}_{2}\right)_{2}{ }^{+}$were carried out using a Apex DUO diffractometer equipped with a Kappa 4-axis goniometer, an APEX II 4K CCD area detector, a Microfocus Source E025 luS using MoK $_{\alpha}$ radiation, Quazar MX multilayer Optics as monochromator and an Oxford Cryosystems low temperature device Cryostream 700 plus $\left(T=-173^{\circ} \mathrm{C}\right)$. Full-sphere data collection was used with $\omega$ and $\varphi$ scans. Data collection with APEX- $2^{28}$, data reduction with Bruker Saint ${ }^{29}$ and absorption correction with SADABS. ${ }^{30}$ Crystal structure solution was achieved using direct methods as implemented in SHELXTL ${ }^{31}$ and visualized using the program XP. Missing atoms were subsequently located from difference Fourier synthesis and added to the atom list. Least-squares refinement on $\mathrm{F}^{2}$ using all measured intensities was carried out using the program SHELXTL. All non-hydrogen atoms were refined including anisotropic displacement parameters. Complex $3^{\text {"I' }}\left(\mathrm{OH}_{2}\right)_{2}{ }^{+}$crystallizes with water molecule, half triflate anion and half hexafluorophosphate anion in the asymmetric unit. The triflate and hexafluorophosphate anions are located on a mirror plane shared with the neighbouring asymmetric unit. Both anions are showing large ellipsoids due to a disorder around the mirror plane which could not be properly refined (CCDC is 1566809). The asymmetric unit in the crystal structure of compound $\mathbf{8}\left(4^{\prime \prime}+\mathbf{7}^{\prime \prime}\right)^{+}$ 
contains a molecule of $4^{11}$ and one of $7^{11,+}$, where one of the carboxylato groups is protonated (CCDC is 1566810).

\section{Results and Discussion}

\section{Synthesis and solid-state structure}

The strategy for the preparation of the Ru-tda complexes is summarized in Scheme 1. Reaction of $\left[\mathrm{Ru}^{\prime \prime} \mathrm{Cl}_{2}(\mathrm{dmsO})_{4}\right]$ with $\mathrm{tda}^{2-}$ in methanol at reflux for six hours yields a brown precipitate. Upon dissolving the solid in water it generates the neutral complex [Ru"(tda-K-N $\left.\left.\mathrm{N}^{3} \mathrm{O}\right)(\mathrm{dmso})\left(\mathrm{OH}_{2}\right)\right], 4^{\prime \prime}$, in reasonable good yields ( $50 \%$ ). Complex $4^{\prime \prime}$ has been characterized in solution by spectroscopic and electrochemical techniques and in the solid state by single-crystal X-ray Diffraction (XRD). Crystals suitable for XRD were collected upon slow evaporation of a $4^{\prime \prime}$ solution in water. The unit cell contains two different complexes that include the initial $4^{\prime \prime}$ complex together with its aquated derivative [Ru" $\left.\left(\mathrm{Htda}-\mathrm{K}-\mathrm{N}^{3}\right)(\mathrm{dmso})\left(\mathrm{OH}_{2}{ }^{\mathrm{ax}}\right)\left(\mathrm{OH}_{2}{ }^{\mathrm{eq}}\right)\right]^{+}, 7^{\mathrm{Il},+}$ (with one craboxylato group protonated), forming a dinuclear complex $\mathbf{8}\left(\mathbf{4}^{\prime \prime}+\mathbf{7}^{\prime \prime}\right)^{+}$according to equation 1 . Complexes $\mathbf{4}^{\prime \prime}$ and $7^{11,+}$ are strongly interacting via extensive hydrogen bonding described in Figure 1.

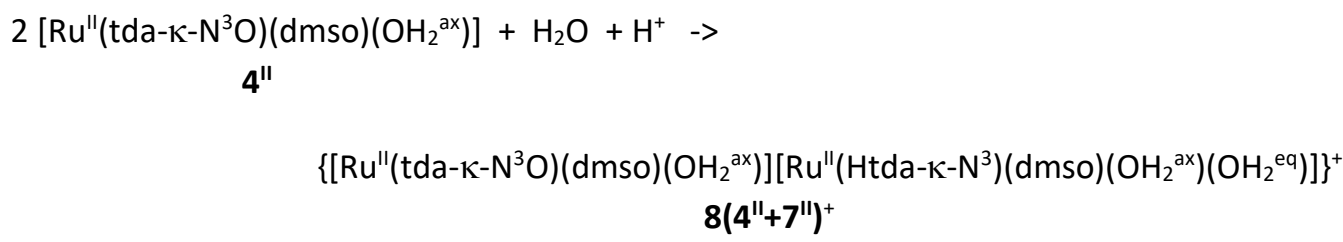

An ORTEP plot ${ }^{32}$ of $4^{11}$ is depicted in Figure 1 and shows a pseudo-octahedral geometry around the Ru metal center expected for a $d^{6} \mathrm{Ru}(\mathrm{II})$ metal ion. In the structure, the tda ${ }^{2-}$ ligand acts in a tetradentate manner occupying the equatorial positon of the Ru center, with the three pyridyl moieties and one carboxylate group bonded to the Ru center and one non-bonded dangling carboxylate. Finally, the axial positons are occupied by an aquo and dmso ligand. An ORTEP plot of $7^{11,+}$ is also illustrated in Figure 1 where the tda ${ }^{2-}$ ligand acts as meridional tridentate ligand and the two carboxylates are not bonded to the metal center. Instead an aquo ligand is coordinated to Ru in the free equatorial position and thus is situated cis with regard to the axial aqua and dmso ligands that complete the octahedral coordination. Here, it is interesting to note the geometrical distortion imposed by the tda ${ }^{2-}$ ligand. Scheme 2 shows the ORuN and NRuN angles in the equatorial plane for $4^{11}$ and $7^{11,+}$. For $4^{\prime \prime}$ it is striking to see $125^{\circ} \mathrm{NRuO}$ angle, that deviates by $35^{\circ}$ from the ideal $90^{\circ}$ for an octahedral coordination. When the carboxylato coordination atom is replaced by the monodenate aqua ligand in $7^{\mathrm{II},+}$, the geometrical restriction imposed by the now (tda- $\left.\kappa-\mathrm{N}^{3}\right)^{2-}$ ligand is released and the two ORuN angles decrease down to $100^{\circ}$ and $99^{\circ}$.

The strong geometric distortion imposed by the $\mathrm{tda}^{2-}$ ligand has significant consequences in the Ru-tda complexes depending on the oxidation state of the Ru center. At oxidation state II it fosters a dynamic behavior in solution whereas at oxidation state III and above it favors the formation of six and a half and seven coordinated Ru complexes. Both phenomena will be described below.

While complex $\mathbf{8}\left(4^{\prime \prime}+\mathbf{7}^{\prime \prime}\right)^{+}$has been isolated as single-crystals as it will be discussed below,

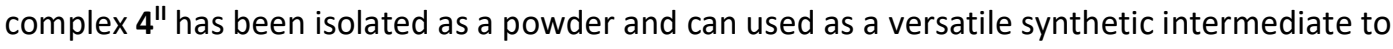


prepare the rest of the complexes described in this work. The versatility of this complex as intermediate arises from the different degree of bonding strength of the three ligands in 4" namely: the $\mathrm{tda}^{2-}$, the dmso and the aqua ligands. The tda ${ }^{2-}$ ligand here acts in a tetradentate- $\kappa-$ $\mathrm{N}^{3} \mathrm{O}$ manner and coordinates in the equatorial position very strongly. In sharp contrast, the axial aquo ligand is a very labile ligand that will be easily replaced by other monodentate ligands. Finally, the dmso ligand is situated in an intermediate coordination strength between the tda ${ }^{2-}$ and aqua ligand.

Consequently, treatment of complex $4^{11}$ with pyridine under mild conditions (stirring at RT), generates complex $5^{\prime \prime}$ according to the following equation,

$$
\begin{array}{cc}
{\left[R u^{\prime \prime}\left(\text { tda- }-\mathrm{N}^{3} \mathrm{O}\right)(\mathrm{dmso})\left(\mathrm{OH}_{2}{ }^{\mathrm{ax}}\right)\right]+\mathrm{py}->} & {\left[\mathrm{Ru}^{\prime \prime}\left(\mathrm{tda}-\kappa-\mathrm{N}^{3} \mathrm{O}\right)(\mathrm{dmso})(\mathrm{py})\right]+\mathrm{H}_{2} \mathrm{O}} \\
\mathbf{4}^{\prime \prime} & \mathbf{5}^{\prime \prime}
\end{array}
$$

Where the initial aqua ligand has been substituted by pyridine. Under harsher conditions, at 100 ${ }^{\circ} \mathrm{C}$, with excess pyridine both the dmso and aquo ligands are substituted generating the bis pyridine complex 6",

$$
\begin{aligned}
& {\left[\mathrm{Ru}^{\prime \prime}\left(\mathrm{tda}-\kappa-\mathrm{N}^{3} \mathrm{O}\right)(\text { dmso })\left(\mathrm{OH}_{2}{ }^{\mathrm{ax}}\right)\right]+2 \mathrm{py}->\left[\mathrm{Ru}^{\prime \prime}\left(\mathrm{tda}-\kappa-\mathrm{N}^{3} \mathrm{O}\right)(\mathrm{py})_{2}\right]+\text { dmso }+\mathrm{H}_{2} \mathrm{O}} \\
& 4^{\prime \prime} \quad 6^{\prime \prime}
\end{aligned}
$$

\section{6"}

The isolated yields for $5^{\prime \prime}$ and $6^{\prime \prime}$ are above 70\% although both reactions (equations 2 and 3) proceed virtually in a quantitative manner as evidenced electrochemically.

Further, the solubilization of $4^{\prime \prime}$ in neat triflic acid $\left(\mathrm{CF}_{3} \mathrm{SO}_{3} \mathrm{H}\right)$, followed by heating at $100{ }^{\circ} \mathrm{C}$ for four hours in an open atmosphere, produces the removal of the pyridine and an dmso axial ligands, presumably by triflate anions and the aerial oxidation of $\mathrm{Ru}(\mathrm{II})$ to $\mathrm{Ru}(\mathrm{III})$, as indicated in equation 4 ,

$\left[\mathrm{Ru}^{\prime \prime}\left(\mathrm{tda}-\mathrm{K}-\mathrm{N}^{3} \mathrm{O}\right)(\mathrm{dmso})\left(\mathrm{OH}_{2}^{\mathrm{ax}}\right)\right]+2 \mathrm{CF}_{3} \mathrm{SO}_{3}^{-}-1 \mathrm{e}^{-}->$

$4^{\prime \prime}$

$$
\left[\mathrm{Ru}^{\prime \prime \prime}\left(\text { tda- } \mathrm{\kappa}-\mathrm{N}^{3} \mathrm{O}\right)\left(\mathrm{CF}_{3} \mathrm{SO}_{3}\right)_{2}\right]^{-}+\mathrm{dmsO}+\mathrm{H}_{2} \mathrm{O}
$$

In aqueous solution the labile triflato ligands are easily substituted by aquo ligands forming the trans-bis-aquo-Ru complex indicated in equation 5,

$$
\left[\mathrm{Ru}^{\prime \prime \prime}\left(\mathrm{tda}-\kappa-\mathrm{N}^{3} \mathrm{O}\right)\left(\mathrm{CF}_{3} \mathrm{SO}_{3}\right)_{2}\right]^{-}+2 \mathrm{H}_{2} \mathrm{O}->\left[\text { trans-Ru' }\left(\text { tda- }-\mathrm{N}^{3} \mathrm{O}\right)\left(\mathrm{OH}_{2}{ }^{\mathrm{ax}}\right)_{2}\right]^{+}+2 \mathrm{CF}_{3} \mathrm{SO}_{3}{ }^{-}
$$

Addition of $\mathrm{PF}_{6}^{-}$to this solution precipitates the complex with a mixed counter anions $\left\{\left[3\left(\mathbf{O H}_{2}\right)_{2}\right]\left(\mathrm{PF}_{6}\right)_{0.5}\left(\mathrm{CF}_{3} \mathrm{SO}_{3}\right)_{0.5}\right\}$, in $75 \%$ isolated yield. This complex has also been characterized in the solid state by XRD and the ORTEP plot of its hydrated cation is illustrated in Figure 1. The $\mathrm{Ru}(\mathrm{III})$ center displays a distorted pentagonal bipyramid geometry where the axial positions are occupied by the two aqua groups and the five equatorial positions are occupied by the bonding atoms of the $\mathrm{tda}^{2-}$ ligand. Here the three $\mathrm{N}$ and one $\mathrm{O}$ have the typical $\mathrm{Ru}(\mathrm{III})-\mathrm{N}$ and $\mathrm{Ru}(\mathrm{III})-\mathrm{O}$ 
bonding distance $\mathrm{s}^{20,25,33}$ while one of the Ru-O carboxylates appears at $2.4 \AA$, and thus is basically a contact, see Table $\mathrm{S} 1$ for the comparison of the distances of different Ru-tda complexes in the II and III oxidation state. This exotic distance arises because the geometrical nature of the ligand clearly forces the metal coordination towards a pentagonal bipyramid geometry although the complex is a $d_{5} \mathrm{Ru}(\mathrm{III})$ and cannot be 7-coordinated. We name the exotic coordination as 6.5 (see Figure 1).

\section{Solution behavior}

Complexes 4", 5" and 6" are all diamagnetic Ru(II) low spin $\mathrm{d}^{6}$ ions and were characterized by NMR spectroscopy in a $\mathrm{D}_{2} \mathrm{O}$ solution containing $0.1 \mathrm{M} \mathrm{CF}_{3} \mathrm{SO}_{3} \mathrm{D}(p D=1.0)$. Complex $3^{\prime \prime \prime}\left(\mathrm{OH}_{2}\right)_{2}{ }^{+}$is paramagnetic due to its $\mathrm{d}^{5}$ electronic configuration. ${ }^{20,25}$ The complex was reduced in situ with ascorbic acid to generate the corresponding diamagnetic complex $\mathbf{3}^{\prime \prime}\left(\mathrm{OH}_{\mathbf{2}}\right)_{\mathbf{2}}$. All their NMR spectra are presented in Figure 2.

Complexes $5^{\mathrm{II}}$ and $6^{\mathrm{II}}$ contain axial pyridyl ligands and the resonances of the pyridyl ligands appear in the 6.5-8.1 ppm region whereas those of the tda $\mathrm{ta}^{2-}$ ligand appear at lower fields. Besides, it is interesting to realize that the $\mathrm{tda}^{2-}$ resonances appear as if the ligand was coordinated in a symmetrical manner. This is due to the fast dynamic behavior that exists in these complexes where the bonded and dangling carboxylate synchronically decoordinate and coordinate respectively, as displayed graphically in the upper part of Scheme 3 . This dynamic behavior is fostered by the geometrical constrains imposed by the tda ${ }^{2-}$ ligand that strongly distorts from an ideal octahedral geometry at the equatorial zone and at the same time provides for an additional bonding carboxylate site in very close proximity. Further in water as a solvent, this dynamic behavior is also in equilibrium with the coordination of a solvent water in the equatorial position as indicated in the lower part of Scheme 3 . This is clearly evidenced in the case of $4^{\prime \prime}$ where in the crystallization process generates $7^{11,+}$. However, in solution this species is clearly very minor as evidenced electrochemically based on their respective redox potentials. It thus points out that the isolation of $7^{11,+}$ is accomplished thanks to a lower solubility of the crystallized species $\mathbf{8}\left(4^{\prime \prime}+7^{\prime \prime}\right)^{+}$with regard to that of $4^{\prime \prime}$ alone.

This behavior in the Ru(II) oxidation state is radically different to the behavior of the Ru-tda complexes at $\mathrm{Ru}(\mathrm{IV})$ oxidation state. In the latter case, the tda- ligands in low coordinating organic solvents, favors a seven coordination environment for this $\mathrm{d}^{4}$ ion, with a pentagonal bipyramid geometry and with the $\mathrm{tda}^{2-}$ ligands acting in $\kappa-\mathrm{N}^{3} \mathrm{O}^{2}$ fashion, as previously described. ${ }^{20}$ Further in aqueous solution at $p H=7.0$ or in basic solution, one bonded carboxylate of complex $6^{\text {II }}$ in the IV oxidation state can be replaced by a hydroxido ligand generating the seven coordinated active catalyst $\mathbf{1}^{\mathrm{IV}}(\mathbf{O H})^{+}$, depicted in Chart $2 .^{20}$

\section{Electrochemical properties}

The electrochemical properties of the Ru-tda complexes were investigated by Cyclic Voltammetry (CV) and Differential Pulse Voltammetry (DPV) techniques by using a Glassy Carbon as a working electrode and $\mathrm{Hg} / \mathrm{Hg}_{2} \mathrm{SO}_{4}$ as a reference electrode. All potentials were converted to NHE by adding $0.65 \mathrm{~V}$. 
The CV of complex $3^{\prime \prime \prime}\left(\mathrm{OH}_{2}\right)_{2}{ }^{+}$at $p H=1.0$ is shown in Figure 3 left, and shows two reversible waves at $E_{1 / 2}=0.52 \mathrm{~V}(\Delta E=60 \mathrm{mV})$ and at $E_{1 / 2}=0.94 \mathrm{~V}(\Delta E=60 \mathrm{mV})$. These redox events correspond to single outer sphere electron transfer processes associated with the III/II and IV/III redox couples respectively. No proton transfer is associated to these couples as evidenced by the Pourbaix diagram shown in Figure 4, right. Figure 3 right shows the DPV of complexes $3^{\prime \prime \prime}\left(\mathrm{OH}_{2}\right)_{2}{ }^{+}, 4^{\prime \prime}, 5^{\prime \prime}$ and $6^{\prime \prime}$ at $p H=1.0$ together with the related complex $\mathbf{2}^{\prime \prime \prime}\left(\mathrm{OH}_{2}\right)^{+}$. The $E_{1 / 2}$ for these complexes are presented in Table 1, together with other redox and thermodynamic data of related Ru polypyridyl complexes. The DPV for all complexes exhibit a couple of waves associated with the III/II and IV/III redox couples (see entries 1-5 Table 1). Here, it is interesting to see that complexes $4^{\prime \prime}$ and $5^{\prime \prime}$, which contain the DMSO ligand, have redox potentials about 200-250 mV higher than complexes $2^{\prime \prime \prime}\left(\mathrm{OH}_{2}\right)_{2}{ }^{+}, 3^{\prime \prime \prime}\left(\mathrm{OH}_{2}\right)_{2}{ }^{+}$and $6^{\prime \prime}$, which only contain py and aquo ligands. The increase of potential is associated with the electron withdrawing character of the dmso ligand as has been previously documented. ${ }^{34}$ On the other hand, the electronic effect exerted by the pyridyl ligand compared to the aquo ligands can be nicely observed by comparing complexes $2^{\prime \prime \prime}\left(\mathrm{OH}_{2}\right)^{+}, 3^{\prime \prime \prime}\left(\mathrm{OH}_{2}\right)_{2}{ }^{+}$and $6^{\prime \prime}$ (entries 4,5 and 3 respectively). where the $\pi$-acceptor character of pyridine cathodically shifts the $E_{1 / 2}$ values by approximately $30 \mathrm{mV}$ in both couples.

It is also interesting to compare the potentials of the IV/III and III/II redox couples for $3^{\prime \prime \prime}\left(\mathrm{OH}_{2}\right)_{2}{ }^{+}$ with those of other related Ru complexes containing polypyridyl ligands such as [Ru" $\left.(\mathrm{bpy})_{3}\right]^{2+}$, $9^{11,2+}\left(E_{1 / 2}(I I I / I I)=1.26 \mathrm{~V}\right.$; bpy is $2,2^{\prime}$-bipyridine; Table 1 , entry 6$) .{ }^{35}$ For $9^{11,2+}$ the III/II couple is anodically shifted by $740 \mathrm{mV}$ with regard to that of $3^{\prime \prime \prime}\left(\mathrm{OH}_{2}\right)_{2}{ }^{+}$which is due to strong sigmadonation effect exerted by the carboxylates of the $\mathrm{tda}^{2-}$ ligands. Further, it is interesting to note that the potential for the second oxidation to reach $\mathrm{Ru}(\mathrm{IV})$ is out of solvent limits and it has never been measured. In sharp contrast, the second wave of $3^{\prime \prime \prime}\left(\mathrm{OH}_{2}\right)_{2}{ }^{+}$, the IV/III couple, is $420 \mathrm{mV}$ more positive than the III/II couple due to the formation of a seven coordinated complex $\left[\mathrm{Ru}^{\mathrm{IV}}\left(\text { tda- } \mathrm{\kappa}-\mathrm{N}^{3} \mathrm{O}^{2}\right)\left(\mathrm{OH}_{2}{ }^{\mathrm{ax}}\right)_{2}\right]^{+}$where the tda ${ }^{2-}$ acts now as pentadentate $\mathrm{k}-\mathrm{N}^{3} \mathrm{O}^{2}$ ligand.

Further, it is also interesting to compare the potentials of the IV/III and III/II redox couples for $3^{\text {"II }}\left(\mathrm{OH}_{2}\right)_{2}{ }^{+}$with those of other related Ru-aquo complexes containing polypyridyl ligands at $\mathrm{pH}=$ 1.0 such as $\left[\mathrm{Ru} \text { "(trpy)(bpy) }\left(\mathrm{OH}_{2}\right)\right]^{2+}, \mathbf{1 0}\left(\mathrm{OH}_{2}\right)^{2+}\left(E_{1 / 2}(\mathrm{III} / \mathrm{II})=1.04 \mathrm{~V}, E_{1 / 2}(\mathrm{IV} / \mathrm{III})=1.23 \mathrm{~V}\right.$; trpy is 2,2':2", $6^{\prime}$-terpyridine; Table 1, entry 7). ${ }^{36}$ Here the potentials for $\mathbf{1 0}\left(\mathbf{O H}_{2}\right)^{2+}$ are significantly lower than $9^{11,2+}$ but still more positive than those of $3^{\prime \prime \prime}\left(\mathrm{OH}_{2}\right)_{2}{ }^{+}$, as a consequence of the absence of anionic sigma donating ligands and the presence of Ru-aqua groups that enables proton coupled electron transfer (PCET) processes.

The redox properties of complex $3^{\prime \prime \prime}\left(\mathrm{OH}_{2}\right)_{2}{ }^{+}$were also studied as a function of the $\mathrm{pH}$ and its Pourbaix diagram is depicted in Figure 4 right. The $\mathrm{CV}$ of $3^{\prime \prime \prime}\left(\mathrm{OH}_{2}\right)_{2}{ }^{+}$at $p H=7.0$ is shown in Figure 4 left, where four one-electron redox process occur in the $0.4-1.2 \mathrm{~V}$ range. The degree of proton content of the different generated species is inferred from its Pourbaix diagram. Thus in this particular case at $\boldsymbol{p H}=\mathbf{7 . 0}$ the III/II couple involves also a proton transfer (approx. $60 \mathrm{mV} / \mathrm{pH}$ slope) whereas the IV/III involves only a single electron transfer ( $0 \mathrm{mV} / \mathrm{pH}$ slope). Further, the $\mathrm{V} / \mathrm{IV}$ now involves a one-electron two-protons transfer (approx. $120 \mathrm{mV} / \mathrm{pH}$ slope) and finally the $\mathrm{VI} / \mathrm{V}$ wave is a one-electron one-proton transfer with an approx. $60 \mathrm{mV} / \mathrm{pH}$ slope. The access to five different reversible oxidation states thanks to PCET mechanisms is exceptional for complexes containing just a single metal center. ${ }^{17}$ This extremely rich redox chemistry of $3^{\prime \prime \prime}\left(\mathrm{OH}_{2}\right)_{2}{ }^{+}$parallels that of $\left[\text {trans-Ru' }(\mathrm{bpy})_{2}\left(\mathrm{OH}_{2}{ }^{\mathrm{ax}}\right)_{2}\right]^{2+}$ complex, $11^{\prime \prime}\left(\mathrm{OH}_{2}\right)_{2}{ }^{2+}$, and [cis- 
$\left.\left.\mathrm{Ru}(\mathrm{bpy})_{2}\left(\mathrm{OH}_{2}{ }^{\mathrm{ax}}\right)_{2}\right)\right]^{2+}$ complex, $\mathbf{1 2}^{\prime \prime}\left(\mathrm{OH}_{2}\right)_{2}{ }^{2+}$, reported earlier (see Table 1, entries 8 and 9 for selected values and Figure S14 for their Pourbaix diagrams). ${ }^{37}$ The redox potential values and the shape of the diagram differ from those of $3^{\prime \prime \prime}\left(\mathrm{OH}_{2}\right)_{2}{ }^{+}$due to the different electronic and geometrical effects exerted by $\mathrm{tda}^{2-}$ compared to bpy. The $\mathrm{tda}^{2-}$ increases the electron density around the metal center in comparison to bpy and provides access to seven coordination. In addition, this increase in electron density is also reflected in an increase of basicity for the Ru species that contain hydroxido or oxo groups. This is clearly observed when comparing the first and second $p K_{\mathrm{a}} \mathrm{s}$ for the Ru $\mathrm{u}^{\mathrm{IV}}\left(\mathrm{OH}_{2}\right)_{2}$ species in $\mathbf{3}$ and $\mathbf{1 1}$ (entries 5 and 8 in Table 1). For $\mathbf{3}$, the first $p K_{\mathrm{a}}=4$ whereas for $\mathbf{1 1}$ the first $\mathrm{pKa}<1$ while the second $p K_{\mathrm{a}}$ is higher than $\mathbf{8}$ for $\mathbf{3}$ and lower than 1 for 11 . Thus the dicarboxylato ligand $t_{d a}{ }^{2-}$, renders the $\mathrm{Ru}(\mathrm{IV})$ species at least 10 million times more basic than the bpy ligand.

Interestingly, the Pourbaix diagram of complex $3^{\prime \prime \prime}\left(\mathrm{OH}_{2}\right)_{2}{ }^{+}$shows that the potentials for the III/II and IV/III couples are very similar to the ones reported earlier for $\mathbf{2}^{\text {III }}\left(\mathrm{OH}_{2}\right)^{+} \cdot{ }^{25}$ The similarity is a consequence of the fact that the replacement of one of the aqua ligands by a pyridyl maintains almost unchanged the potentials and the $p K_{a}$ at oxidation state II, III and IV (see Table 1 for the values and Figure S15 for the Pourbaix diagram of $\left.\mathbf{2}^{\prime \prime \prime}\left(\mathrm{OH}_{2}\right)^{+}\right)$. However, the Pourbaix diagram of complex $3^{\prime \prime \prime}\left(\mathrm{OH}_{2}\right)_{2}{ }^{+}$strongly differs from that of $\mathbf{2}^{\prime \prime \prime}\left(\mathrm{OH}_{2}\right)^{+}$at higher oxidation states than Ru(IV). While complex $2^{\text {III }}\left(\mathrm{OH}_{2}\right)^{+}$only undergoes a single electron transfer beyond oxidation state IV, complex $3^{\prime \prime \prime}\left(\mathrm{OH}_{2}\right)_{2}{ }^{+}$can access all the way up to $\mathrm{Ru}(\mathrm{VI})$ forming the trans-Ru-dioxo species. This difference is due to the higher number of protons that can be lost in $3^{\prime \prime \prime}\left(\mathrm{OH}_{2}\right)_{2}{ }^{+}$with two Ru-aquo groups as compared to $\mathbf{2}^{\prime \prime \prime}\left(\mathrm{OH}_{2}\right)^{+}$with only one Ru-aquo group.

Finally, it is interesting to notice that the VI/V couple for $3^{\mathrm{V} 1}(\mathrm{O})_{2}$ is well above the thermodynamic potential for the oxidation of water to dioxygen and thus could potentially act as a water oxidation catalyst. Unfortunately, decomposition reactions possibly involving polymeric oxobridged type of species such as the ones described for $\mathbf{1 0}^{1 \mathrm{v}}(\mathrm{OH})^{3+}$ (see Figure S16), can compete with the catalytic reaction. ${ }^{38,39}$

\section{Implications for water oxidation catalyst design}

Here we report the synthesis and characterization of $3^{\prime \prime \prime}\left(\mathrm{OH}_{2}\right)_{2}{ }^{+}$that completes the family of seven coordinated Ru-tda complexes bearing different aqua/pyridine ligands in the axial position as drawn in Chart 2 . While $\mathbf{1}^{\mathrm{IV}}(\mathbf{O H})^{+}$is a spectacular catalyst reaching maximum TOF in the order of $50000 \mathrm{~s}^{-1}$, the replacement of one pyridine by a hydroxido to generate $2^{\mathrm{iv}}(\mathrm{OH})^{+}$ renders this complex still a catalyst but very poor due to the lack of access to hydrogen bonding. Additional replacement of the pyridine ligand by a second hydroxido ligand generates the bishydroxido complex $3^{1 \mathrm{~V}}(\mathrm{OH})_{2}{ }^{+}$that even though has the right redox potential for water oxidation unfortunately decomposes quickly towards the formation of polymeric oxo-bridged species. It thus suggests the need of non-aqua ligands or non-labile ligands to block the formation of highly stable oxo-bridged Ru complexes.

Thus the present work enlarges the landscape of Ru-tda complexes and uncovers additional factors that influence the water oxidation catalysis namely, the presence of one or two Ru-aqua groups, the seven coordination and the presence of anionic ligands and their implication in both $p K_{a}$ and redox potentials, the capacity to generate the proper intramolecular hydrogen bonding and the avoidance of oxo-bridged formation 


\section{Associated Content}

The Supporting Information is available free of charge via the Internet at http://pubs.acs.org. Additional characterization data and electrochemical results as well as X-ray data and CIF for $3^{\text {"I' }}\left(\mathrm{OH}_{2}\right)_{2}{ }^{+}$, and $8^{+}$.

\section{Acknowledgments}

MINECO and FEDER (CTQ2016-80058-R, CTQ2015-64261-R, SEV 2013-0319, ENE2016-82025REDT, CTQ2016-81923-REDC) and AGAUR (2014-SGR-915) are gratefully acknowledge for financial support. R.M. thanks "La Caixa" foundation for a PhD grant. 
Scheme 1. Synthetic strategy for the preparation of the complexes described in this work (colored) and nomenclature used. Key axial and equatorial ligands are indicated with a "ax" or "eq" super index respectively.
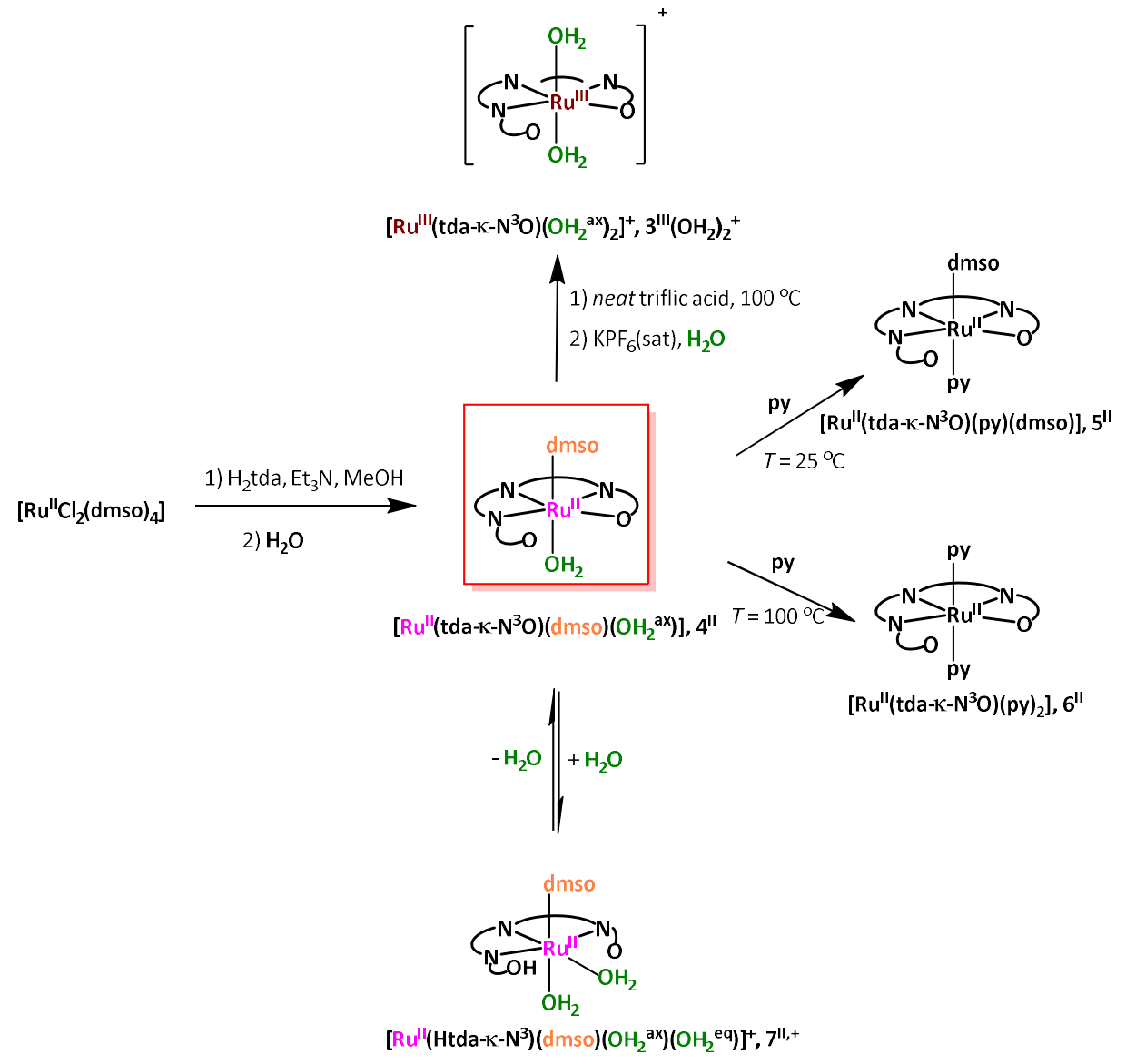
Scheme 2. Selected angles for the equatorial first coordination sphere of complexes 4", $7^{11,+}$ and $3^{\prime \prime \prime}\left(\mathrm{OH}_{2}\right)_{2}{ }^{+}$. Axial ligands are omitted for clarity. Dashed line indicates contact.

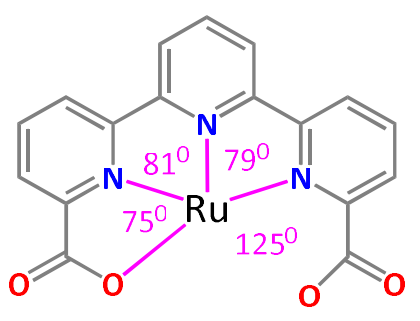

$4^{\prime \prime}$<smiles></smiles>

$7^{11,+}$

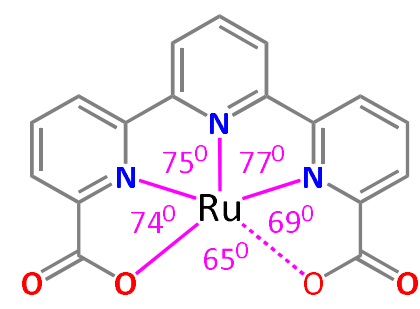

$3^{\prime \prime \prime}\left(\mathrm{OH}_{2}\right)_{2}^{+}$

Scheme 3. Reaction pathways leading to a combination of equilibria involved in dynamic behaviour of Ru-tda complexes in water. The dashed lines indicate bonds that are simultaneously formed and broken in the transition state. L-Ax represents the axial ligands py, dmso or aquo.

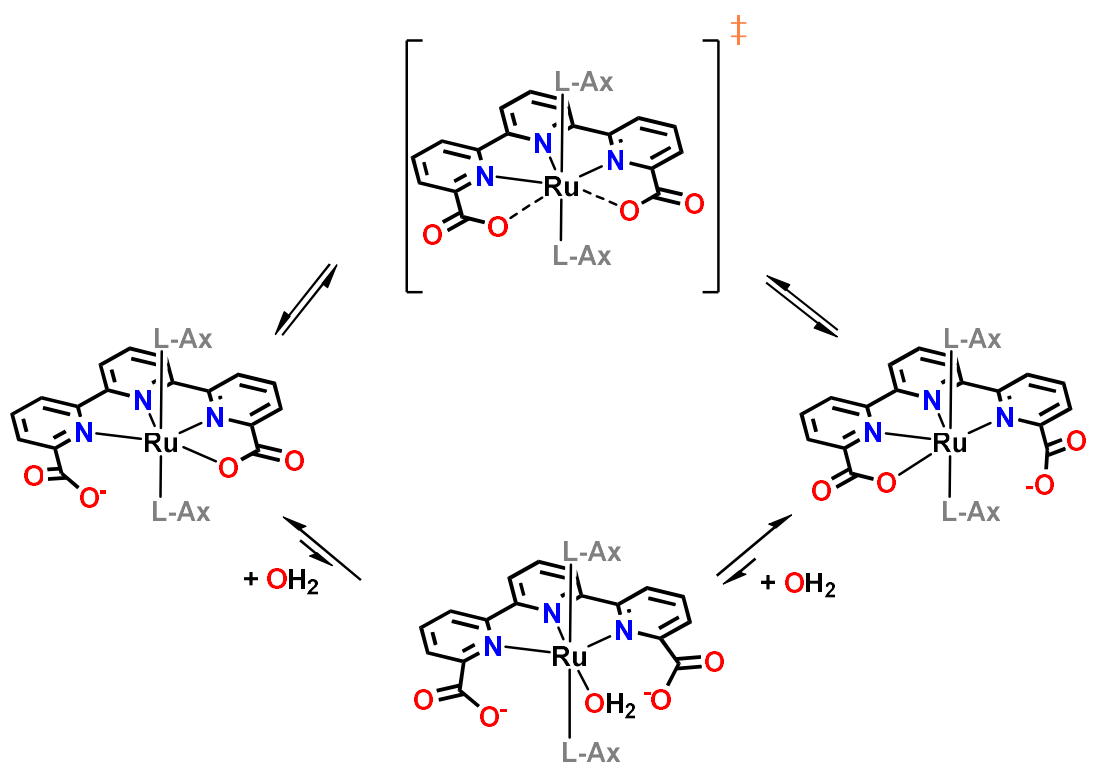



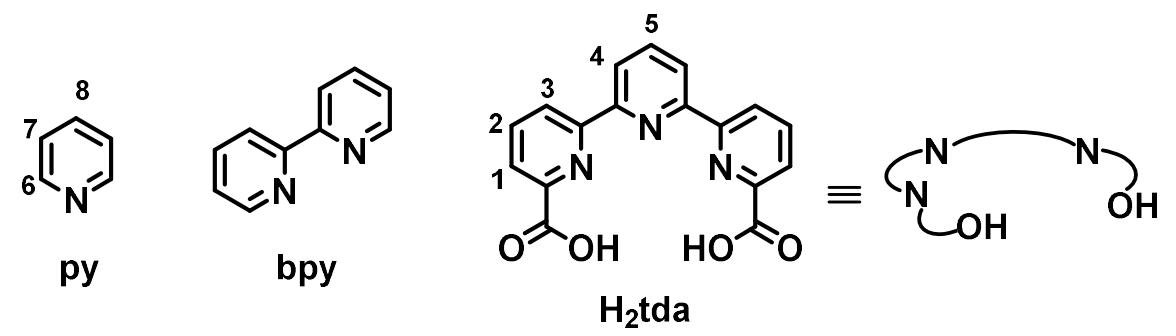

Chart 1. Ligands used and/or discussed in this work together with the labelling and numbering schemes.

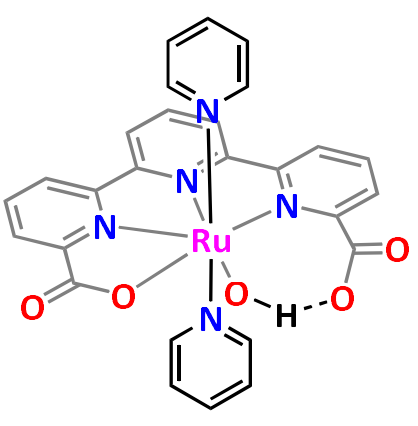

$1^{\text {IV }}(\mathrm{OH})^{+}$

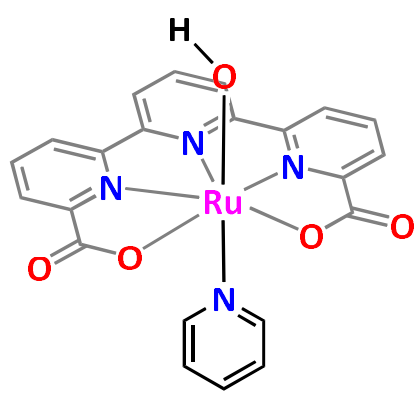

$2^{\text {IV }}(\mathrm{OH})^{+}$

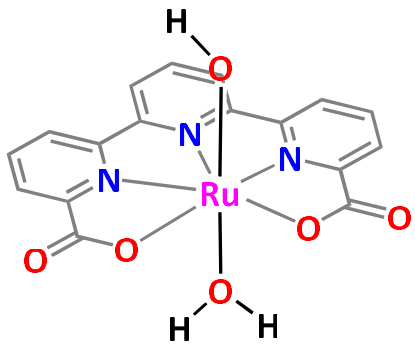

$3^{\mathrm{IV}}(\mathrm{OH})\left(\mathrm{OH}_{2}\right)^{+}$

Chart 2. Ru hydroxido-pyridine complexes based on the tda- ligand. ${ }^{20,25}$ Complexes $\mathbf{2}^{\text {iv }}(\mathrm{OH})^{+}$ and $3^{\mathrm{IV}}(\mathrm{OH})\left(\mathrm{OH}_{2}\right)^{+}$are the one-electron oxidized forms of $2^{\mathrm{II \prime}}(\mathrm{OH})_{2}{ }^{+}$and $3^{\prime \prime \prime}\left(\mathrm{OH}_{2}\right)_{2}{ }^{+}$at $\mathrm{pH}>4$. 


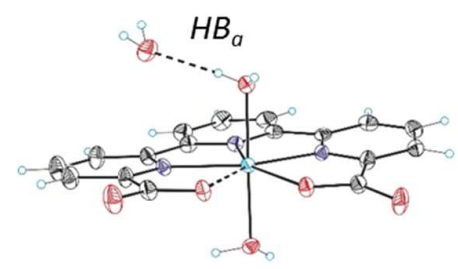

$3^{\prime \prime \prime}\left(\mathrm{OH}_{2}\right)_{2}$
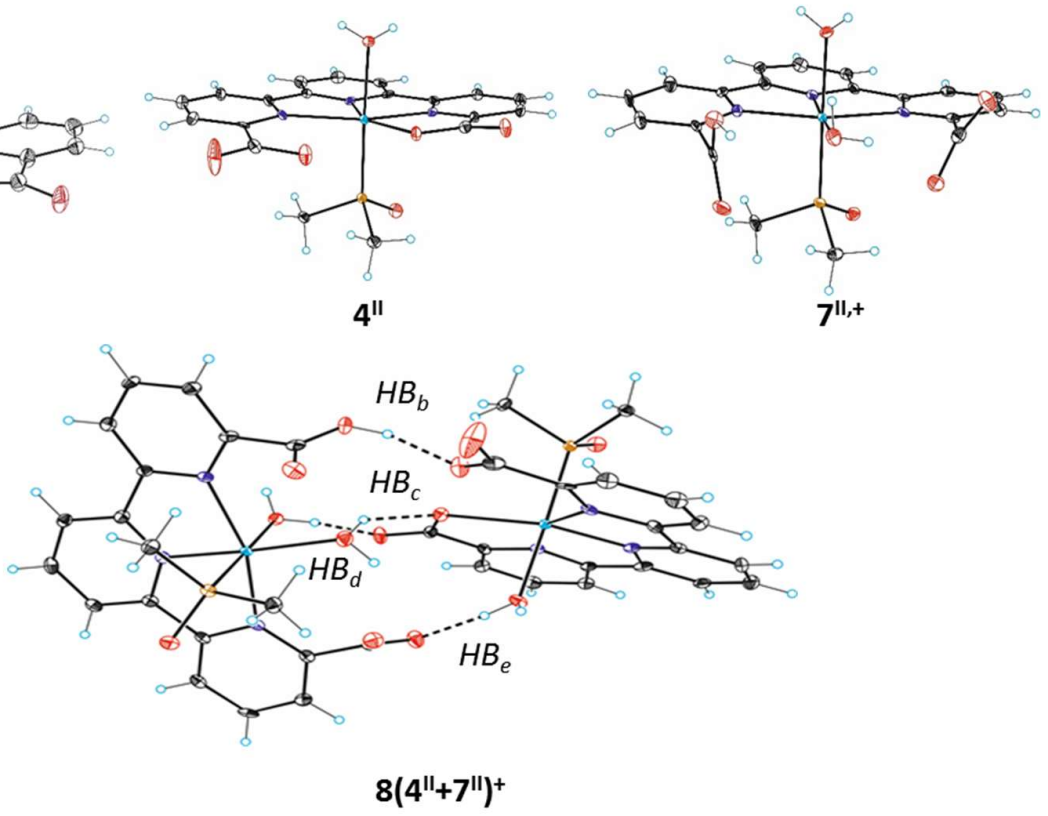

Figure 1. ORTEP plot for complexes $3^{\prime \prime \prime}\left(\mathrm{OH}_{2}\right)_{2}{ }^{+}, \mathbf{8}\left(4^{\prime \prime}+7^{\prime \prime}\right)^{+}$and fragments of $\mathbf{8}\left(4^{\prime \prime}+\mathbf{7}^{\prime \prime}\right)^{+}: \mathbf{4}^{\prime \prime}$ and $7^{11,+}$. Ellipsoids are plotted at $50 \%$ probability. Dashed lines indicate contacts. Color codes: Ru, cyan; N, purple; O, red; $\mathrm{C}$, black and $\mathrm{H}$; colorless. Hydrogen bond distances $(\mathrm{O}-\mathrm{H}-\mathrm{O}): H B_{a}$, do-H$\mathrm{O}=2.6 \AA$, d $\mathrm{d}_{\mathrm{O}-\mathrm{H}}=0.7 \AA$, $\mathrm{d}_{\mathrm{O}-\mathrm{H}}=1.9 \AA$ $;$ angle $\mathrm{O}-\mathrm{H}-\mathrm{O}=186^{\circ} ; H B_{b}, \mathrm{~d}_{\mathrm{O}-\mathrm{H}-\mathrm{O}}=2.5 \AA$, $\mathrm{d}_{\mathrm{O}-\mathrm{H}}=0.9 \AA$, $\mathrm{d}_{\mathrm{O}-\mathrm{H}}=$ $1.7 \AA$; angle O-H-O $=153^{\circ} ; H B_{c}$, d $\mathrm{d}_{\mathrm{O}-\mathrm{H}-\mathrm{O}}=2.8 \AA$, $\mathrm{d}_{\mathrm{O}-\mathrm{H}}=0.9 \AA$, $\mathrm{d}_{\mathrm{O}-\mathrm{H}}=2.0 \AA$; angle O-H-O $=143^{\circ}$; $H B_{d}, 2.5 \AA \mathrm{d}_{\mathrm{O}-\mathrm{H}}=0.9 \AA \AA$, d $\mathrm{d}_{\mathrm{O}-\mathrm{H}}=1.65 \AA$; angle $\mathrm{O}-\mathrm{H}-\mathrm{O}=171^{\circ} ; H B_{e}, 2.5 \AA . \mathrm{d}_{\mathrm{O}-\mathrm{H}}=0.9 \AA$ A, $\mathrm{d}_{\mathrm{O}-\mathrm{H}}=1.66$ $\AA$; ; angle $\mathrm{O}-\mathrm{H}-\mathrm{O}=152^{\circ}$ 


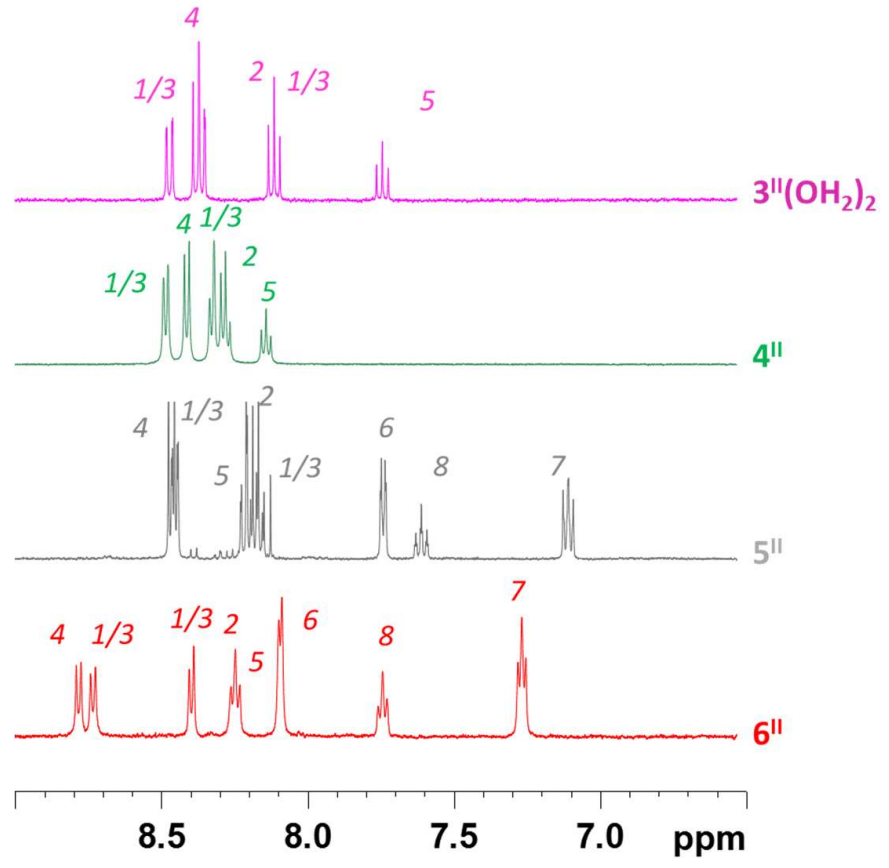

Figure 2. ${ }^{1} \mathrm{H}$ NMR spectra for $3^{\prime \prime}\left(\mathrm{OH}_{2}\right)_{2}, 4^{\prime \prime}, 5^{\prime \prime}$ and $6^{\prime \prime}$ at $p D=1.0$ solution. See Chart 1 for the numbering scheme. 

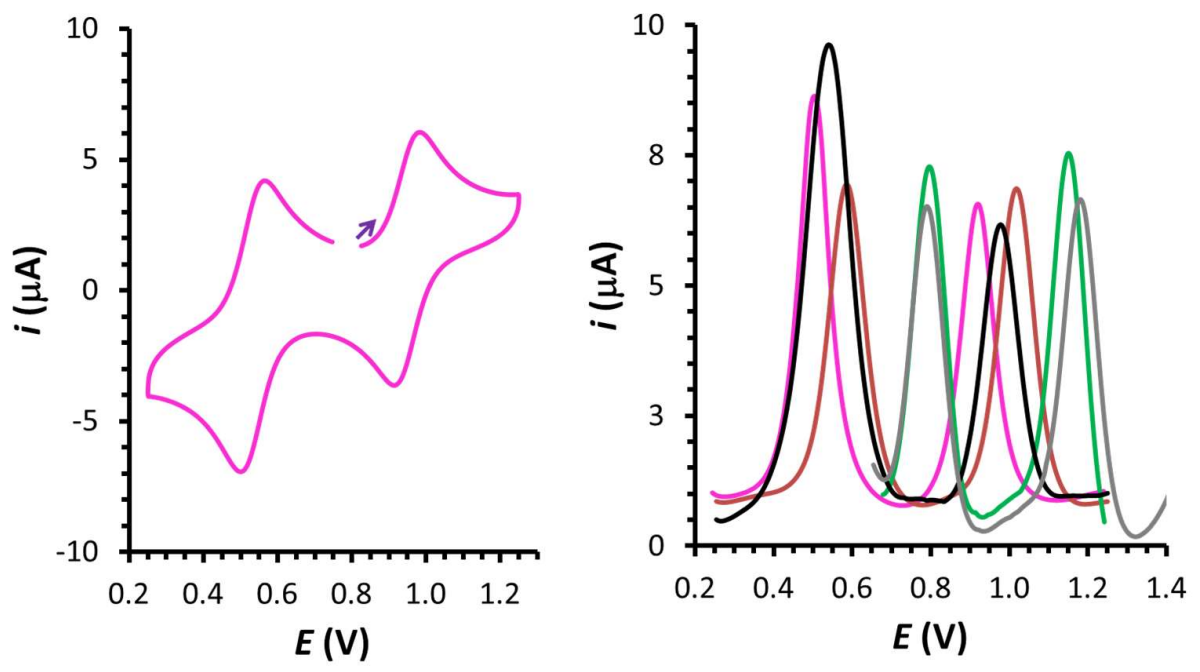

Figure 3. Left, $\mathrm{CV}$ of complex $3^{\text {"I' }}\left(\mathrm{OH}_{2}\right)_{2}{ }^{+}$at $p H=1.0$. Right, DPV of complexes $\mathbf{2}^{\text {"I' }}\left(\mathrm{OH}_{2}\right)^{+}$ (black line), $3^{\prime \prime \prime}\left(\mathrm{OH}_{2}\right)_{2}{ }^{+}$(pink line), 4" (green line), 5" (grey line), 6" (brown line) at $\mathrm{pH}=$ 1.0. $E$ is reported vs. NHE. 

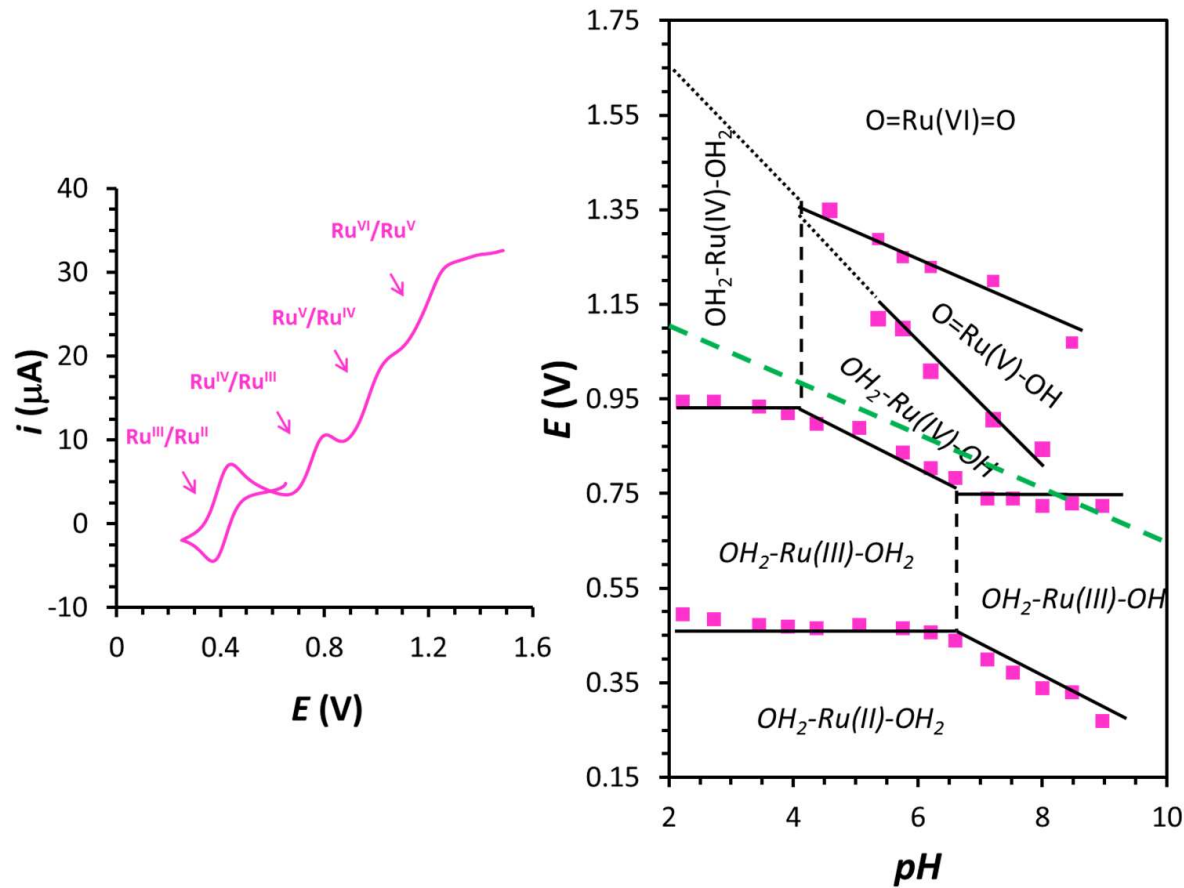

Figure 4. Left, blank corrected Cyclic Voltammetry (CV) for $0.5 \mathrm{mM} \mathrm{3} 3^{\prime \prime \prime}\left(\mathrm{OH}_{2}\right)_{2}{ }^{+}$at $p H=7.0$. The arrows indicate the redox couples involved in the redox events. Right, Pourbaix diagram of $3^{\prime \prime \prime}\left(\mathrm{OH}_{2}\right)_{2}{ }^{+}$, showing the zone of predominance of the different species as function of potential and $p H$ (the tda ${ }^{2-}$ ligand is omitted for clarity). Vertical dashed lines indicate $p K_{a}$ values. The green dashed line indicates the thermodynamic potential for $\mathrm{O}_{2} / \mathrm{H}_{2} \mathrm{O}$ redox couple. 
Table 1. Thermodynamic properties for complexes $3^{\prime \prime \prime}\left(\mathrm{OH}_{2}\right)_{2}{ }^{+}, 4^{\prime \prime}$ and other relevant Ru complexes described previously.

\begin{tabular}{|c|c|c|c|c|c|c|c|c|}
\hline \multirow[b]{2}{*}{ Entry } & \multirow[b]{2}{*}{ Complex } & \multicolumn{3}{|c|}{$E^{o}(\mathrm{~V} v s . \mathrm{NHE})^{\mathrm{a}}$} & \multicolumn{2}{|r|}{$\mathrm{pK}_{\mathrm{a}}$} & \multirow[b]{2}{*}{$\mathrm{Ru}^{\mathrm{IV}}\left(\mathrm{OH}_{2}\right)(\mathrm{OH})$} & \multirow[b]{2}{*}{ Ref } \\
\hline & & III/II & IV/III & $\mathrm{VI} / \mathrm{IV}$ & $\mathrm{Ru}^{\mathrm{IV}} \mathrm{OH}_{2}$ & $\mathrm{Ru}^{\mathrm{IV}}\left(\mathrm{OH}_{2}\right)_{2}$ & & \\
\hline 1 & 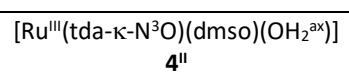 & 0.80 & 1.15 & --- & --- & --- & --- & t.w. \\
\hline 2 & $\begin{array}{c}{\left[\mathrm{Ru}^{\prime \prime \prime}\left(\mathrm{tda}-\mathrm{K}^{\left.-\mathrm{N}^{3} \mathrm{O}\right)}(\mathrm{dmso})(\mathrm{py})\right]\right.} \\
\mathbf{5}^{\prime \prime}\end{array}$ & 0.59 & 1.02 & --- & --- & --- & --- & t.w., 25 \\
\hline 3 & $\begin{array}{c}{\left[\mathrm{Ru}{ }^{\prime \prime \prime}\left(\mathrm{tda}-\mathrm{K}-\mathrm{N}^{3} \mathrm{O}\right)(\mathrm{py})_{2}\right]} \\
6^{\prime \prime}\end{array}$ & 0.80 & 1.18 & --- & --- & -- & --- & t.w., 20 \\
\hline 4 & $\begin{array}{c}{\left[\mathrm{Ru}^{\prime \prime \prime \prime}\left(\mathrm{tda}-\kappa-\mathrm{N}^{3} \mathrm{O}\right)(\mathrm{py})\left(\mathrm{OH}_{2}{ }^{\mathrm{ax}}\right)\right]^{+}} \\
\mathbf{2}^{\prime \prime \prime}\left(\mathrm{OH}_{2}\right)^{+}\end{array}$ & 0.54 & 0.97 & --- & 3.9 & --- & --- & 25 \\
\hline 5 & $\begin{array}{c}\left.\left[\text { trans-Ru"'I(tda- } \kappa^{\prime \prime}-\mathrm{N}^{3} \mathrm{O}\right)\left(\mathrm{OH}_{2}{ }^{\mathrm{ax}}\right)_{2}\right]^{+} \\
\mathbf{3}^{\prime \prime \prime}\left(\mathrm{OH}_{2}\right)_{2}{ }^{+}\end{array}$ & 0.52 & 0.94 & $>1.75$ & --- & 4.0 & $>8$ & t.w. \\
\hline 6 & $\begin{array}{c}{\left[\mathrm{Ru}^{\prime \prime}(\mathrm{bpy})_{3}\right]^{2+}} \\
\mathbf{9}^{11,2+}\end{array}$ & 1.26 & --- & --- & --- & --- & --- & 35 \\
\hline 7 & $\begin{array}{c}{\left[\mathrm{Ru}^{\prime \prime}(\text { trpy)})(\mathrm{bpy})\left(\mathrm{OH}_{2}\right)\right]^{2+}} \\
10^{\prime \prime}(\mathrm{OH})^{2+}\end{array}$ & 1.04 & 1.23 & 1.80 & $<1.0$ & --- & --- & 36 \\
\hline 8 & $\begin{array}{c}\left.\left.[\text { trans-Ru"(bpy })_{2}\left(\mathrm{OH}_{2}{ }^{\mathrm{ax}}\right)_{2}\right)\right]^{2+} \\
11^{\prime \prime}\left(\mathrm{OH}_{2}\right)_{2} 2^{2+}\end{array}$ & 0.69 & 1.13 & $1.26^{b}$ & --- & $<1.0$ & $<1.0$ & 37 \\
\hline 9 & $\begin{array}{c}{\left[c i s-\mathrm{Ru}^{\prime \prime}(\mathrm{bpy})_{2}\left(\mathrm{OH}_{2}{ }^{\mathrm{ax}}\right)_{2}\right]^{2+}} \\
\mathbf{1 2}^{\prime \prime}\left(\mathrm{OH}_{2}\right)_{2^{2+}}\end{array}$ & 0.80 & 1.15 & $1.42^{b}$ & --- & $<1.0$ & $<1.0$ & 37 \\
\hline
\end{tabular}

\footnotetext{
${ }^{a}$ measured at $p H=1.0$

${ }^{\mathrm{b}}$ calculated from the $\mathrm{VI} / \mathrm{V}$ and $\mathrm{V} / \mathrm{IV}$ redox couples.
} 


\section{References}

${ }^{1}$ Bruneau, C. Ruthenium catalysts and fine chemistry; Springer-Verlag: Berlin, 2004.

2 Pal, A. K.; Hanan, G. S. Chem. Soc. Rev. Design, synthesis and excited-state properties of mononuclear Ru(II) complexes of tridentate heterocyclic ligands. 2014, 43, 6184-6197.

${ }^{3}$ Colasson, B.; Credi, A.; Ragazzon, G. Light-driven molecular machines based on ruthenium(II) polypyridine complexes: Strategies and recent advances. Coord. Chem. Rev. 2016, 325, 125-134. ${ }^{4}$ Jiang, C. W.; Chao, H.; Hong, X. L.; Li, H.; Mei, W. J.; Ji, L. N. Enantiopreferential DNA-binding of a novel dinuclear complex [(bpy $\left.)_{2} \mathrm{Ru}(\mathrm{bdptb}) \mathrm{Ru}(\mathrm{bpy})_{2}\right]^{4+}$. Inorg. Chem. Commun. 2003, 6, 773-775. ${ }^{5}$ Ossipov, D.; Gohil, S.; Chattopadhyaya, J. Synthesis of the DNA-[Ru(tpy) $\left.(\mathrm{dppz})\left(\mathrm{CH}_{3} \mathrm{CN}\right)\right]^{2+}$ conjugates and their photo cross-linking studies with the complementary DNA strand. J. Am. Chem. Soc. 2002, 124, 13416-13433.

${ }^{6}$ Giri, R.; Thapa, S.; Kafle, A. Palladium-catalysed, directed C-H coupling with organometallics. Adv. Synth. Catal. 2014, 356, 1395-1411.

${ }^{7}$ Doyle, M. P.; Duffy, R.; Ratnikov, M.; Zhou, L. Catalytic carbene insertion into C-H Bonds. Chem. Rev. 2010, 110, 704-724.

8 Punniyamurthy, T.; Velusamy, S.; Iqbal, J. Recent advances in transition metal catalyzed oxidation of organic substrates with molecular oxygen. Chem. Rev. 2005, 105, 2329-2364.

${ }^{9}$ Lewis, N. S. Research opportunities to advance solar energy utilization. Science 2016, 351, 19201-19209.

${ }^{10}$ McCrory, C. C. L.; Jung, S.; Ferrer, I. M.; Chatman, S. M.; Peters, J. C.; Jaramillo, T. F. Benchmarking hydrogen evolving reaction and oxygen evolving reaction electrocatalysts for solar water splitting devices. J. Am. Chem. Soc. 2015, 137, 4347-4357.

${ }^{11}$ Garrido-Barro, P.; Gimbert-Suriñach, C.; Matheu, R.; Sala, X.; Llobet, A. How to make an efficient and robust molecular catalyst for water oxidation. Chem. Soc. Rev. 2017, doi: 10.1039/C7CS00248C.

${ }^{12}$ Blakemore, J. D.; Crabtree, R. H.; Brudvig, G. W. Molecular catalysts for water oxidation. Chem. Rev. 2015, 115, 12974-13005.

${ }^{13}$ Gersten, S. W.; Samuels, G. J.; Meyer, T. J. Catalytic oxidation of water by an oxo-bridged ruthenium dimer. J. Am. Chem. Soc. 1982, 104, 4029-4030.

${ }^{14}$ Sens, C.; Romero, I.; Rodriguez, M.; Llobet, A.; Parella, T.; Benet-Buchholz, J. A new Ru complex capable of catalytically oxidizing water to molecular dioxygen. J. Am. Chem. Soc. 2004, 126, 7798-7799.

${ }^{15}$ Concepcion, J. J.; Tsai, M. K.; Muckerman, J. T.; Meyer, T. J. Mechanism of water oxidation by single-site ruthenium complex catalysts. J. Am. Chem. Soc. 2010, 132, 1545-1557.

${ }^{16}$ Nyhlén, J.; Duan, L.; Åkermark, B.; Sun, L.; Privalov, T. Evolution of $\mathrm{O}_{2}$ in a seven-coordinate $\mathrm{Ru}^{\mathrm{IV}}$ dimer complex with a $[\mathrm{HOHOH}]^{-}$bridge: A computational study. Angew. Chem. Int. Ed. 2010, 49, 1773-1777.

${ }^{17}$ Huynh, M. T.; Mora, S. J.; Villalba, M.; Tejeda-Ferrari, M. E.; Liddell, P. A.; Cherry, B. R.; Teillout, A.-L.; Machan, C. W.; Kubiak, C. P.; Gust, D.; Moore, T. A.; Hammes-Schiffer, S.; Moore, A. L. Concerted one-electron two-proton transfer processes in models inspired by the tyr-his couple of photosystem II. ACS Cent. Sci. 2017, 3, 372-380.

${ }^{18}$ Gagliardi, C. J.; Vannucci, A. K.; Concepcion, J. J.; Chen, Z.; Meyer, T. J. The role of proton coupled electron transfer in water oxidation. Energy Environ. Sci. 2012, 5, 7704-7717.

${ }^{19}$ Duan, L.; Fischer, A.; Xu, Y.; Sun, L. Isolated seven-coordinate Ru (IV) dimer complex with $[\mathrm{HOHOH}]^{-}$bridging ligand as an intermediate for catalytic water oxidation. J. Am. Chem. Soc. 2009, 131, 10397-10399.

${ }^{20}$ Matheu, R.; Ertem, M. Z.; Benet-Buchholz, J.; Coronado, E.; Batista, V. S.; Sala, X.; Llobet, A. Intramolecular proton transfer boosts water oxidation catalyzed by a Ru complex. J. Am. Chem. Soc. 2015, 137, 10786-10795. 
${ }^{21}$ Duan, L.; Bozoglian, F.; Mandal, S.; Stewart, B.; Privalov, T.; Llobet, A.; Sun, L. A molecular ruthenium catalyst with water-oxidation activity comparable to that of photosystem II. Nat. Chem. 2012, 4, 418-423.

${ }^{22}$ Tong, L.; Inge, A. K.; Duan, L.; Wang, L.; Zou, X.; Sun, L. Catalytic water oxidation by mononuclear Ru complexes with an anionic ancillary ligand. Inorg. Chem. 2013, 52, 2505-2518.

${ }^{23}$ Li, F.; Li, L.; Tong, L.; Daniel, Q.; Gothelid, M.; Sun, L. Immobilization of a molecular catalyst on carbon nanotubes for highly efficient electro-catalytic water oxidation. Chem. Commun. 2014, 50, 13948-13951.

${ }^{24}$ Fan, T.; Duan, L.; Huang, P.; Chen, H.; Daniel, Q.; Ahlquist, M. S. G.; Sun, L. The Ru-tpc water oxidation catalyst and beyond: water nucleophilic attack pathway versus radical coupling pathway. ACS Catal. 2017, 7, 2956-2966.

${ }^{25}$ Matheu, R.; Ertem, M. Z.; Gimbert-Suriñach, C.; Benet-Buchholz, J.; Sala, X.; Llobet, A. Hydrogen bonding rescues overpotential in seven-coordinated Ru water oxidation catalysts. ACS Catal. 2017, 6525-6532

${ }^{26}$ Galaup, C.; Couchet, J.-M.; Bedel, S.; Tisnès, P.; Picard, C. Direct access to terpyridinecontaining polyazamacrocycles as photosensitizing ligands for $\mathrm{Eu}(\mathrm{III})$ luminescence in aqueous media. J. Org. Chem. 2005, 70, 2274-2284.

${ }^{27}$ Evans, I. P.; Spencer A.; Wilkinson, G. Dichlorotetrakis(dimethyl sulphoxide)ruthenium(II) and its use as a source material for some new ruthenium(II) complexes. J. Chem. Soc., Dalton Trans. 1973, 204-209.

${ }^{28}$ Data collection with APEX II version v2013.4-1. Bruker (2007). Bruker AXS Inc., Madison, Wisconsin, USA.

${ }^{29}$ Bruker SAINT version V8.30c. Bruker (2007). Bruker AXS Inc., Madison, Wisconsin, USA.

${ }^{30}$ SADABS: V2012/1 Bruker (2001). Bruker AXS Inc., Madison, Wisconsin, USA. Blessing, Acta Cryst. (1995) A51 33-38.

${ }^{31}$ Sheldrick, G.M. Acta Cryst. 2008, A64, 112-122. SHELXTL version V6.14.

32 Johnson Carroll K, 1965. "OR TEP: A FORTRAN Thermal-Ellipsoid Plot Program for Crystal Structure Illustrations". ONRL Report \#3794. Oak Ridge, Ten., Oak Ridge National Laboratory.

${ }^{33}$ Richmond, C. J.; Matheu, R.; Poater, A.; Falivene, L.; Benet-Buchholz, J.; Sala, X.; Cavallo, L.; Llobet, A. Supramolecular water oxidation with Ru-bda-based catalysts. Chem. Eur. J. 2014, 20, 17282-17286.

${ }^{34}$ Mognon, L.; Benet-Buchholz, J.; Llobet, A. single site isomeric Ru WOCs with an electronwithdrawing group: Synthesis, electrochemical characterization, and reactivity. Inorg. Chem. 2015, 54, 11948-11957.

${ }^{35}$ Berardi, S.; Francas, L.; Neudeck, S.; Maji, S.; Benet-Buchholz, J.; Meyer, F.; Llobet, A. Efficient light-driven water oxidation catalysis by dinuclear ruthenium complexes. ChemSusChem 2015, 8, 3688-3696.

${ }^{36}$ Wasylenko, D. W.; Ganesamoorthy, C.; Henderson, M.; Koivisto, B. D.; Osthoff, H.; Berlinguette, C. P. Electronic modification of the $\left[\mathrm{Ru}^{\prime \prime} \text { (tpy)(bpy) }\left(\mathrm{OH}_{2}\right)\right]^{2+}$ scaffold: Effects on catalytic water oxidation. J. Am. Chem. Soc. 2010, 132, 16094-16106.

${ }^{37}$ Dobson, J. C.; Meyer, T. J. Redox properties and ligand loss chemistry in aqua/hydroxo/oxo complexes derived from cis- and trans-[(bpy $\left.)_{2} \mathrm{Ru}^{\prime \prime}\left(\mathrm{OH}_{2}\right)_{2}\right]^{2+}$. Inorg. Chem. 1988, 27, 3283-3291.

${ }^{38}$ López, I.; Maji, S.; Benet-Buchholz, J.; Llobet, A. Oxo-bridge scenario behind single-site wateroxidation catalysts. Inorg. Chem. 2015, 54, 658-666.

${ }^{39}$ López, I.; Ertem, M. Z.; Maji, S.; Benet-Buchholz, J.; Keidel, A.; Kuhlmann, U.; Hildebrandt, P.; Cramer, C. J.; Batista, V. S.; Llobet, A. A self-improved water-oxidation catalyst: Is one site really enough? Angew. Chem. Int. Ed. 2014, 53, 205-209. 
We report a novel trans-dioxo $\mathrm{Ru}$ complex containing the pentadentate $\mathrm{tda}^{2-}$ ligand $\left(\mathrm{tda}^{2-}=\right.$ $\left[2,2^{\prime}: 6^{\prime}, 2^{\prime \prime}\right.$-terpyridine]-6,6"-dicarboxylate). The seven-coordinate trans-di-oxo complex reaches $\mathrm{V}$ and $\mathrm{VI}$ oxidation states at relative low potentials as evidenced by electrochemical analysis. The comparison of its rich electrochemistry with other water oxidation catalysts allows the rationalization of the factors that influence the water oxidation reaction catalyzed by molecular complexes.

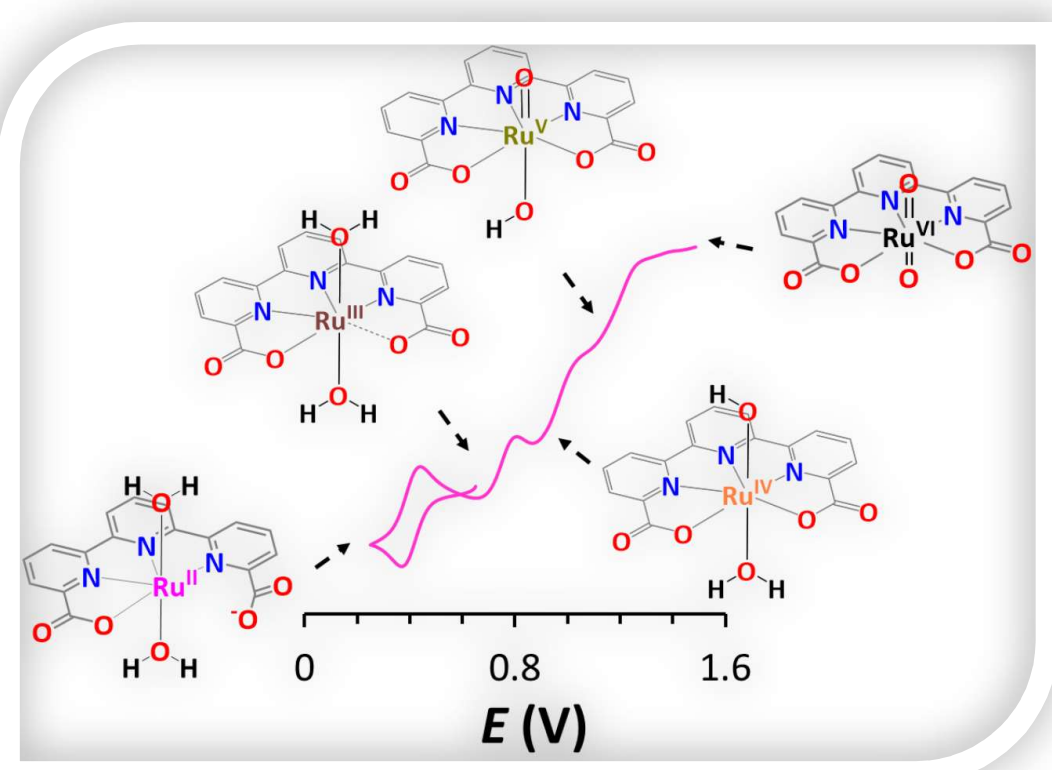

